\title{
I6
}

ALEXANDRA BARRATT

\section{Continental women mystics and English readers}

In I 406 Sir Henry (later Lord) Fitzhugh, trusted servant of King Henry IV, visited Vadstena, the Bridgettine monastery for men and women in Sweden. Vadstena was the mother-house of the Order of the Most Holy Saviour and had been founded by the controversial continental mystic St Bridget of Sweden, who had died in 1373 and had been canonized in I39r. Fitzhugh was so impressed by what he saw that he gave one of his manors near Cambridge as the future site for an English Bridgettine foundation. It was not until 14I5 that Henry V, son of Henry IV, laid the foundation-stone of Syon Abbey at Twickenham in Middlesex and Fitzhugh's dream became a reality. But Fitzhugh's generous gesture is an indication of the degree of pious and aristocratic interest in the Swedish visionary and prophet in early fifteenth-century England.

\section{Margery of Lynn; Julian of Norwich}

Two years earlier, in I4I3, Margery Kempe of Lynn in East Anglia had been granted an interview by Philip Repingdon, Bishop of Lincoln. His visitor intrigued him; he listened sympathetically to her account of her spiritual experiences and then made an unusual suggestion:

sche schewyd hym hyr meditacyons and hy [high] contemplacyons and other secret thyngys bothe of qwyk [living] and ded as Owyr Lord schewyd [revealed] to hire sowle. He was rygth glad to heryn hem [them] ... cownselyng [advising] hire sadly [seriously] that hire felyngys [thoughts] schuld be wretyn [written (down)] ...

To Margery the idea that she should have her spiritual experiences set down in writing had the shock of the new, and she refused, saying that this was not God's will. But to Repingdon Margery must have seemed a fascinating home-grown variety of a species with which he, as a late medieval Latinate 
and cosmopolitan cleric, would have been familiar: the European woman mystic.

At the time Repingdon made his unsettling suggestion, there were no indigenous, vernacular texts by women mystics in circulation in England. Indeed, it has been convincingly argued that English religious women were actively discouraged from pursuing this type of spirituality, let alone recording the results in writing. The fifteenth-century Book for a Simple and Devout Woman cautions against cultivating visions and other paranormal religious experiences, for these open the door to vanity and pride:

My dere suster, my consaile is bat bu fizte azeyn [fight against] vayneglorie [vanity], for perof pu art moste fondud [tempted]. Dremes and siztes [visions] pat pu seest in pi slepe, zeue to hem no feipe [credence]. Lyft byn herte holiche from hem and haue hem alle suspecte, ne tel no worde bi [about] hem to non to wite what pey wolde mene. Sopfaste sizte [true vision] is, and of parfite mede [(deserving) perfect reward], knowynge of byself, porw be whiche quyknep [comes to life] knowyng of God and vnyte wip hym. ${ }^{2}$

The pursuit of self-knowledge is preferable, and the clerical author urges his charge, rather than trying to scale the dangerous heights of contemplation, to stick to the ascetic, purgative way:

Of penaunce and of hardschip [austerity] siker bup [sure are] pe weyes [ways], and of contemplacion vnstabele [uncertain] and somdel to drede [somewhat to be feared]. So perlus hit is on hyz [high] to clymbe, and siker wei [sure way] to God hit is pat mon holde hym lowe [one should consider oneself as humble]. Aungeles office [function] hit is heuenliche pyngus [things] to knowe and to wite [know] be pryuytes [secrets] bat mow not be departed [shared]. Hit is inow [enough] to mon to se his owne lodliche [ugly] synnes. ${ }^{3}$

But such advice was not universally followed. Forty years before Margery's visit, in May I373, a young woman on the point of death had experienced sixteen visions of the crucified Christ. At the time she was 'thirty and one half years old', and was later to become an anchoress in Repingdon's own diocese, attached to a church just a short walk from his cathedral. Not long after her miraculous recovery, Julian of Norwich described her experiences in the Short Version of A Revelation of Love. But there is no evidence that her text, so intensively studied today, circulated widely, if at all, in the Middle Ages. It survives in just one fifteenth-century manuscript, which belonged to a Carthusian monastery, BL MS Additional 37790 (the Amherst Manuscript). Fifteen or twenty years later Julian recast this as the Long 
Version, the earliest surviving complete manuscripts of which are as late as the seventeenth century.

Julian is frequently mentioned in Norwich wills: people left her money, but there is not a single piece of evidence that they knew of her writings or her revelations. Margery Kempe consulted her because she enjoyed a reputation as a spiritual adviser: 'the ankres was expert in swech thyngys and good cownsel cowd yevyn' ( $B M K$, pp. $42 / 7-43 / 20)$. But in the detailed, and very convincing, account that she gives of their conversations, neither woman refers to Julian's visions, though the irrepressible Margery cannot resist mentioning her own 'many wondirful reuelacyons' (BMK, p. 42/I4).

Nonetheless, in continental Europe there was a long tradition (or rather several traditions) of women visionaries, quantitatively far more important than the native English strain. Repingdon must have been familiar with some of them, at least, as their texts circulated in both Latin and vernacular versions. They were read and owned by devout lay men and women of the aristocracy, the gentry, and the urban middle class, as well as by monks, nuns, and other religious, as we shall see.

\section{Hildegard of Bingen}

The great twelfth-century Benedictine saint and abbess, Hildegard of Bingen (I098-II79), visionary, poet, musician, scientific and medical writer, wrote prolifically if eccentrically in Latin. But she was known in medieval England in her less familiar role as an apocalyptic prophetess (hence her epithet 'the Sibyl of the Rhine'), rather than as a mystic. Possibly Repingdon saw Margery Kempe as a potential 'Sibyl of the Ouse': as a former supporter of the theologian and heretic John Wyclif (though under pressure he had recanted those radical views and had gone on to become a bishop) he would certainly have known of Hildegard and her writings. For she had, particularly in her 'Cologne letter' of c. II62, apparently prophesied the demands that Wyclif was to make in the late fourteenth century for the disendowment of the Church (that is, that it should be deprived of its extensive lands and temporal possessions). Some of Hildegard's writings were also seen as predicting the rise of the mendicants (principally the Franciscan and the Dominican orders) who owned no property, either individually or collectively, and lived (at least in theory) by begging. Those who disapproved of the new movement were happy to appropriate - even on occasion to forge - her writings.

Consequently, Hildegard probably enjoyed greater fame among the learned than she would have commanded simply as a woman visionary. According to their library catalogue, the brothers of the Bridgettine abbey 
of Syon had once owned (but had lost) a copy of a prophecy about the mendicants. They still possessed at the time of the dissolution of the monasteries a book containing her Scivias, while the Benedictine abbeys of Battle and Glastonbury both owned copies of her complete prophecies. But none of Hildegard's writings were translated into English in the Middle Ages, although in the sixteenth century her Latin texts were printed. So in spite of the renown she has won in the last twenty or thirty years, Julian of Norwich and Margery Kempe very likely knew nothing about her.

Whom else might Repingdon have known? Elizabeth of Schönau (II2664) was, like Hildegard, a Benedictine nun and abbess. She experienced visions and other supernatural manifestations but did not write them down herself. Egbert, her brother, however, composed a life of his sister which recorded her revelations. A mid-thirteenth-century catalogue of the books belonging to the Benedictine Glastonbury Abbey lists a copy, while the late fourteenth-century catalogue of Dover Priory (also a Benedictine house) lists her vision concerning the Assumption of the Blessed Virgin Mary. But, as with Hildegard, though there is some evidence that her Latin life circulated in England, it was never translated into Middle English.

\section{Beguines}

Lives of women visionaries could be important conduits of influence. In the late twelfth and early thirteenth centuries the area around Liège in the north of France and what is now Belgium produced a remarkable flowering of 'holy women'. Many were beguines, that is, women leading a religious life in self-supporting and self-governing communities or sometimes in their own homes, rather than enclosed as contemplative nuns in convents. They were mainly illiterate in Latin, and sometimes even in their vernaculars (principally French and Flemish), but we know of their experiences from their Latin lives or vitae, written by their male confessors or disciples. The Dominican friar, Thomas of Cantimpré, and the cardinal/bishop, Jacques de Vitry, wrote a number of these. De Vitry in particular was a prominent apologist for beguine life and for their spirituality, which foregrounded visionary experiences combined with paranormal phenomena and ferocious asceticism.

There is no evidence that the beguine saints were known in England until the end of the Middle Ages. In the fifteenth century the Augustinian canons of Thurgarton in Yorkshire (where Walter Hilton, the fourteenth-century mystic and author of The Scale of Perfection, retired) owned a life 'of the three virgins Elizabeth, Christina and Marie'. This could well be identical with Oxford Bodley MS Douce II 4, a manuscript connected with the Carthusian order, that contains the only surviving copy of the lives of the beguines 
Elisabeth of Spalbek, Christina the Marvellous (she certainly lived up to her name), and Mary of Oignies, all translated from the Latin into Middle English. ${ }^{4}$ Around the same time, Margery Kempe's confessor was reading Jacques de Vitry's life of Mary of Oignies (either in Latin or English), and it profoundly altered his negative attitude towards Margery's weeping.

Further evidence of beguine influence (apart from that of the treatise by Marguerite Porete, who will be discussed below) occurs right at the end of our period. Marie of Oisterwijk, a Flemish beguine who died as late as I547, lived as a recluse under the protection of the Cologne Charterhouse. (Carthusian monks, both on the continent and in England, played a vital role in encouraging women visionaries and in preserving and circulating their writings.) British Library MS Harley 494 contains an English translation of a devotional exercise addressed to the Five Wounds of Jesus, introduced as 'certain prayers showed unto a devout person called Mary Ostrewyk'. Significantly, perhaps, it is found immediately after an extract from another continental mystical text, Mechthild of Helfta's revelations.

This is a rare example of beguine infiltration into England (where, surprisingly, the movement never took root) but it is not unique. In I533, only months before the execution of the Benedictine nun Elizabeth Barton, the Holy Maid of Kent, The Mirror or Glass of Christ's Passion, by the Bridgettine monk John Fewterer, was printed. This vast and scholarly book is largely concerned with identification with Christ through meditation on his Passion, his sufferings on the cross. The author chooses to present Mary of Oignies, whose life he knew through the Speculum Historiale of the thirteenth-century Dominican friar Vincent of Beauvais, as a model of the benefits such meditation can provide.

\section{Women of Helfta}

In the second half of the thirteenth century a group of women mystics had emerged at the Benedictine monastery of Helfta in Saxony, then under the leadership of its abbess Gertrud of Hackeborn. Her younger sister Mechthild (c. 1240-98), novice mistress and chantress at Helfta, was a visionary but did not herself write down her experiences. This was done in Latin sometime after 1290 by Gertrud of Helfta (I256-I3OI), a younger contemporary to whom she had acted as novice mistress, and by another (anonymous) nun. Mechthild's collected visions constituted the Liber spiritualis (sometimes specialis) gratiae [Book of Spiritual (or Special) Grace]). Gertrud too was an influential visionary and her experiences are recorded in Latin in the Legatus divinae pietatis [The Herald of God's Loving-Kindness]. She wrote Book 2 herself, while others compiled the biography that makes up 
Book $\mathrm{I}$ and the collection of visions in Books 3, 4, and 5. This work was not translated into English in the Middle Ages and was probably not known in England in Latin either.

In contrast, the Liber spiritualis gratiae was well known in England and, although Mechthild is not widely read today, her visions had an extensive and understandable appeal. They are vividly visual, very beautiful, and not obviously unorthodox or alarmingly innovative in their theology. Like those of Gertrud, they particularly encourage devotion to the Heart of Jesus as the quintessence of his human nature, within the context of the sacrament of the Mass and the liturgical year. The Liber was translated into Middle English, although in an abbreviated form. Two manuscripts of this translation, The Book of Ghostly Grace, survive: British Library MS Egerton 2006, which once belonged to Richard III and his wife, Anne of Warwick; and Oxford MS Bodley 220, written by a certain John Wells, who may have been a Carthusian monk.5 Both belong to the fifteenth century.

Possibly a Carthusian monk translated Mechthild's Liber for the Bridgettine nuns of Syon. As we have already mentioned, the Carthusians rather specialized in collecting, studying, and copying the writings of orthodox women mystics. The important Charterhouse (Carthusian monastery) of Sheen was directly opposite Syon on the other side of the River Thames, and relations between the two religious houses were close (though too close for comfort on occasions). Surprisingly, it was the Carthusians, rather than the Bridgettine monks, who seem to have taken the initiative in the spiritual direction of the nuns. Bridgettine nuns, who were highly regarded in fifteenth-century England, took their vocation and the development of their spiritual lives extremely seriously and they needed suitable reading matter in English.

References to Mechthild, known as 'Matilda' or 'Maud' to English readers, and extracts both in English and Latin from her revelations have been identified in a total of nine medieval devotional works and spiritual compilations. These include two in the Bridgettine Myroure of Oure Ladye (see further below); another in the Speculum devotorum, compiled for a nun by a Carthusian; and extracts and passages attributed to Mechthild in several other manuscripts. Many of these have Bridgettine or Carthusian connections and contain texts by other women visionaries popular at Syon, notably Bridget of Sweden and Catherine of Siena.

Copies of both the Latin original and the Middle English translation of Mechthild seem to have been surprisingly common. In the late fourteenth or early fifteenth century, the local vicar donated a collection of books to Swine Priory in Yorkshire, a house of Cistercian nuns. It included a copy of the Liber, probably of the Latin text, even though the gift was made to a house of religious women, who normally could not read Latin. A late 
fifteenth-century book-list shows that the Augustinian canons of Thurgarton owned a copy of Mechthild's revelations, while Syon Abbey owned four complete copies, one in English, and a text printed in I5I3. A manuscript now in Durham University Library (MS Cosin v.iii.16), which belonged to Syon Abbey, contains Latin extracts from the Liber together with a letter in English to the sisters, urging them to read the accompanying texts. And as late as the Elizabethan age, Robert Barker, vicar of Driffield, who died in I 58r, owned a Liber S. Matildis, which had probably come from Byland Abbey in Yorkshire.

Devout lay people also owned Mechthild's revelations. Cicely, Duchess of York, mother of Richard III, who was noted for her piety, is said to have had the book read aloud to her during mealtimes; she bequeathed her copy to her granddaughter Brigitte, a Dominican nun. Alienora (or Eleanor) Roos of York, who died in $\mathrm{I} 438$, owned a text described as 'maulde buke', probably a Middle English version of Mechthild who as we have mentioned was known as Maud in English. This she bequeathed in her will to Dame Joan Courtenay, who was probably a nun.

\section{Marguerite Porete}

Marguerite Porete was a contemporary of Gertrud of Helfta. A beguine from Hainault in Flanders, in r3Io she was burned at the stake in Paris for heresy. The treatise that caused her undoing, Le Mirrouer des simples ames [The Mirror of Simple Souls], was originally written in French. The Inquisition condemned it as heretical on a number of grounds, notably that Marguerite taught that certain favoured souls no longer needed the Church and its sacraments, nor were they obliged to observe the rules of Christian morality. As part of their investigations, the Inquisition had her book translated into Latin, the better to scrutinize and condemn it. Ironically, four of these Latin manuscripts survive while only one, late and corrupt, copy of the French original has come down to us. Marguerite's book was also translated into Italian and into English. ${ }^{6}$

Like Hildegard, Marguerite fascinates modern readers but was little known in England in the Middle Ages. In contrast to the work of many other continental women visionaries, there is no evidence that her text circulated among women readers, possibly because people quickly forgot that a woman had written it. Indeed, The Mirror clearly had a very restricted circulation in England: no wills, catalogues, inventories, or library lists have so far come to light that make any mention of her text. It is true that three manuscripts of the Middle English translation survive, a creditable total for a medieval text. But all three belonged to individual Carthusian monks or to 
Carthusian monasteries, a rarefied and exclusive spiritual milieu. (One copy is found in the same manuscript, BL Add. 37790 , that contains the only copy of the Short Text of Julian's A Revelation of Love.)

Further evidence of Carthusian interest, even sponsorship, of The Mirror is the translation into Latin made by Richard Methley who was a monk at Mount Grace Charterhouse in Yorkshire (the house where the only copy of The Book of Margery Kempe was held). Presumably he knew nothing of the earlier Latin translation made by the Inquisition. Perhaps he made his own translation so that the text, which he must have admired and valued, could be examined with greater theological subtlety. It would also reach a wider clerical audience throughout Europe, as Latin was the international language of the Church.

The three Middle English copies are remarkably similar, even to the extent of conscientiously transmitting obvious gibberish, for the translation is extremely literal. This suggests that the copies must have been produced under tight editorial control, with strict instructions to the scribes to change nothing. The translator, probably a Carthusian, clearly had no idea that the text was heretical, let alone that a woman had written it. But he did betray some unease with the content and from time to time adds defensive explanatory notes marked with his initials, 'M.N.'

\section{Elizabeth of Hungary}

'Elizabeth of Hungary' is a familiar name and a popular saint. She was born in 1207 , the daughter of the Hungarian king, and was briefly but happily married to the Count of Thuringia, to whom she bore several children before he departed and died on Crusade. She then became a model of Franciscan piety and poverty, dying exhausted by her austerities before she was twentyfour in $123 \mathrm{r}$. But it is arguable that the Elizabeth of Hungary whose 'treatise' Margery Kempe cites as providing a precedent for her own weeping ( $B M K$, p. I54/I3-I4) was a different person altogether. This other Elizabeth, born nearly a hundred years later in $\mathrm{I294}$, daughter of another king of Hungary, was a Dominican nun in the Swiss convent of Töss who died in 1336 . Margery (or her confessor) probably had in mind, and was familiar with, the so-called Revelations of St Elizabeth, of which two Middle English versions survive. 7 This is a brief Latin text that largely consists of highly imaginative dialogues between Elizabeth and the Virgin Mary, and later Christ himself. It seems to have appealed to the medieval mind, for it was translated into numerous European languages.

The first Middle English translation survives in a single early fifteenthcentury manuscript, Cambridge University Library MS Hh.I.II. This 
probably belonged to a community of East Anglian nuns, possibly to the Franciscans of Bruisyard, Suffolk. The other version does not survive in manuscript at all but was printed by Wynkyn de Worde, in or around I492, and then reprinted c. I500. It follows a translation of the much longer Life of St Catherine of Siena by her confessor Raymund of Capua. Catherine and her writings, as we shall see, were promoted in England by the Bridgettines of Syon Abbey, who may also have suggested the Elizabeth text to de Worde. It is perhaps significant that the brothers of Syon at one time owned a copy of the revelations in English, which was lost or removed. Perhaps they had lent it to de Worde: early printers often destroyed their copy-text after it had been typeset.

\section{Bridget of Sweden}

All the visionaries mentioned so far have occupied, as it were, niche positions. By far the best known of the continental women mystics, the only one who was in any way a household name and whose followers could count on widespread brand-recognition, was Bridget of Sweden (I302 or 1303-73). ${ }^{8}$ Bridget (or Birgit, or Birgitta) was a very modern saint. Aristocratic; married; a mother (of eight, no less); critic and adviser of popes and kings; foundress of a revolutionary religious order for men and women but never a nun herself; visionary and mystic: she exemplified the 'mixed life' that combined the pursuit of contemplation with active virtue and political involvement, even though the nuns of her own religious order were strictly enclosed. In particular she insistently lobbied for the return of the papacy from Avignon to Rome.

Bridget's writings became increasingly widely read during the fifteenth century, by both lay and religious. The Spanish bishop, Alphonse de Pecha, had definitively fixed the vast Latin text of her revelations, consisting of eight books, some time before $\mathrm{I} 377$. A distinctive and identifiable textual tradition of the Latin prevailed in England, reflected by the two, independent, Middle English translations of the whole text. ${ }^{9}$ There were also separate selections of compilations in Latin, and at least seven survive in Middle English. These tended to draw on those revelations with elements of prophecy, or details about the lives of Christ and the Virgin, or instructions about the spiritual life. In addition, short passages from Bridget's revelations were often copied, and recopied, to fill the odd page or half-page in individual manuscripts.

Many of the prophetic revelations criticized the clergy, and are analogous to the Hildegard material that circulated in England. But Bridget's emphasis on the validity of the priestly office, however immoral the individual priest, 
could also be used against the Wycliftes. Moreover, the Swedish saint had conveniently supported the English claim to the French throne that underlaid the Hundred Years' War: not surprisingly, the relevant revelations were harnessed to the nationalist cause.

Bridgettine material was also absorbed into original works of spiritual instruction. The anonymous but immensely popular Contemplations of the Dread and Love of God $^{\mathrm{TO}}$ contains a great deal of material lifted from the revelations and was in its turn mined by the much-copied Pore Caitiff and by a version of the De remediis contra temptaciones [Remedies against Temptations] by William Flete, spiritual adviser to Catherine of Siena. Similarly, a sermon on the Assumption of the Virgin in Cambridge University Library MS Hh. I.II (which, as we have seen, also contains the only Middle English manuscript version of Elizabeth of Hungary's revelations) draws on several Bridgettine texts. Bridget's vivid though somewhat old-fashioned visions of Christ's Passion frequently appear in compilations and were recycled in other works such as the Carthusian Speculum devotorum and The Fruyte of Redempcyon, printed by Wynkyn de Worde in I5I4. Other extracts were arranged to constitute the Virgin Mary's autobiography as told to Bridget, found in Oxford Bodley MS Rawlinson C 4I. ${ }^{\text {II }}$

There is considerable evidence that Bridget's writings were widespread in later medieval England. The donation to the Cistercian nuns at Swine included a Latin text of Bridget's revelations; Durham University MS Cosin v.iii.I6, already mentioned as containing Mechthild texts, contains Latin extracts; the Augustinian canons at Thurgarton owned a copy of the Latin revelations; the catalogue of the last prior of Monk Bretton, a Cluniac priory, listed a copy. Cambridge University Library MS ii.6.40, which belonged to Johanna Mouresleygh (fl. I44I, I460), a Benedictine nun at Shaftesbury, contains a Bridget extract, in English.

Bridget texts are also mentioned in wills far more often than those of any other woman visionary. In $\mathrm{I}_{4} \mathrm{I} 5 \mathrm{Henry}$ le Scrope, lord of Masham, bequeathed a copy to his brother Stephen, Archdeacon of Richmond. Around I 420 John Dygon, recluse of Sheen, and Johanna, recluse of St Botulph's, London, gave a copy of the revelations to Magdalen College, Oxford. (It is still there, as Oxford, Magdalen MS 77.) In I 432 Robert Semer bequeathed a 'Bridget book' to William Bramley; in I468 Elizabeth Sewerby and in I48I Margaret Purdaunce of Norwich left copies in their wills. In I495 Cicely, Duchess of York, left her copy to her granddaughter Anne de la Pole, while Agnes Vavasour, a Cistercian nun at Swine, was bequeathed books by Bridget, perhaps by her aunt.

Other evidence of Bridget's popularity in England is a verse life, Salutacio Sancte Birgitte, written by the poet John Audelay around $1426,{ }^{12}$ in which 
he praises Syon Abbey, the only English house of the Order of the Most Holy Saviour. There can be no doubt that the presence from I4 I 5 onwards of an extremely pious, wealthy, and well-connected Bridgettine house near London was the primary factor in the circulation of Bridgettine texts and the growth of devotion to the saint. Syon was a focus for pilgrimage, where the famous 'Pardon', or indulgence, could be bought - Margery Kempe herself visited Syon, probably in 1433 (BMK p. $245 / 3 \mathrm{I}-3$ ) - and, given its strong links with Europe, a centre for the dissemination of devotion to St Bridget in particular and up-to-the minute continental cults in general.

Numerous manuscripts of Bridget's revelations and other associated texts directly connected with Syon Abbey are still extant today. Unfortunately, there is no surviving catalogue of the nuns' library (unlike that of the brethren) but much can be reconstructed. ${ }^{13}$ For instance, British Library MS Arundel 146 must have belonged to Syon as it contains the Additions to the Bridgettine rule. ${ }^{14}$ Cambridge University Library MS Ff.6.33 contains extracts from the revelations and may have belonged to the Syon sisters. Syon owned British Library MS Harley $6 \mathrm{I} 2$, an important Latin manuscript that contains a corpus of Bridgettine writings, including the Defensorium Sanctae Birgittae by the Benedictine Adam Easton (d. I397).

The many early sixteenth-century printed editions of the revelations were aimed at a reading public interested in vernacular devotional literature, in the continental mystics, and in the religious life. This interest extended to the highest in the land: in I49I, Lady Margaret Beaufort, mother of Henry VII, together with his wife, Queen Elizabeth, commissioned William Caxton to print an edition of a spurious but extremely popular text attributed to $\mathrm{St}$ Bridget, the Fifteen Oes (STC 20195). Renowned for her piety and learning as well as for her single-minded dedication to the political interests of her son, Lady Margaret had close contacts with Syon. She herself translated two contemporary European devotional works familiar to the Bridgettines: part of Thomas à Kempis's Imitation of Christ, and a penitential text by a Flemish Carthusian monk, The Mirror of Gold to the Sinful Soul. ${ }^{15}$ These were not however written by women, and are devotional rather than mystical.

Among their many idiosyncrasies, the Bridgettine nuns had a distinctive Latin liturgy that Christ himself had dictated to their foundress. ${ }^{16}$ This was translated into English some time after I 435 and was presumably used by the nuns in multiple manuscript copies. In 1530 it was printed as The Myrroure of Oure Ladye, perhaps with the aim of allowing every Syon nun to have her own copy - in blissful ignorance that only nine years later they would be turned out of their monastery by Henry VIII and would go into exile in Flanders. 


\section{Catherine of Siena}

Bridget may have been the best known of the continental women visionaries, but the closest in time to Margery Kempe and Bishop Repingdon was the Italian Catherine of Siena (canonized in I46I). In fact, her dates (I347-80) make her a near contemporary of Julian of Norwich. Although of humbler, bourgeois origins - her father was a wool-dyer - Catherine showed a number of similarities to Bridget. (Significantly, visual representations of the two saints in English early printed books are virtually indistinguishable.) She was an ascetic and visionary, but not an enclosed nun. Rather, she continued to live at home, vowed to virginity as Dominican tertiary (tertiaries were in many ways like beguines) in the midst of her extensive family. She had many followers, both men and women, some of whom acted as her secretaries; she was active in politics, both in urban affairs and in international ecclesiastical diplomacy, demanding (like St Bridget a generation earlier) the return of the papacy to Rome.

Catherine even had a tenuous connection with England, for an English Augustinian friar, William Flete, was her spiritual adviser from I362 to 1374 . (He was succeeded by the better-known Raymund of Capua, a Dominican friar, who wrote the earliest biography of the saint.) This constitutes the only known personal link between the fourteenth-century English and Italian mystics, though there is in fact no evidence that William Flete maintained his links with England or helped circulate Catherine's writings there. But there is evidence for her cult in Britain in the late Middle Ages, including a convent of the Second Order of Dominican nuns, founded in Edinburgh in I 5 I 7 , and dedicated to her. An early sixteenth-century copy of their constitutions and of the gospels to be read at Mass throughout the liturgical year survives as Edinburgh University Library MS $150 .{ }^{17}$

Catherine's principal mystical work, dictated in Italian in 1378 , was known as the Dialogo. As the title suggests, it consists of a series of dialogues: between the soul of the mystic and God the Father. Raymund of Capua translated it into Latin and there is extant an English (or Scottish) manuscript of this version, now Edinburgh University Library MS 87, which was perhaps connected with the Edinburgh Dominican convent. In the early fifteenth century the Latin version was translated into Middle English for the benefit of the Syon nuns, as The Orcherd of Syon: ${ }^{\mathrm{r}}$ three manuscripts survive. Wynkyn de Worde eventually printed it for a wider audience in I 5 I $9 .{ }^{19}$ Syon's spiritual style was very different from the Italian saint's: notably, it lacked the dimension of social activism that made Catherine of Siena a role-model for the nineteenth-century English reformer Josephine Butler. Nonetheless the Bridgettine monastery was closely involved in the dissemination of devotion 
to Catherine, and of knowledge of her life and writings, and the Bridgettine brothers for their part owned a copy of Catherine's vita and two of the Dialogo.

Lives of Catherine, such as that owned by the Syon brethren, were also widely disseminated, and because they were relatively accessible may have been more influential than her somewhat demanding visionary writings. The Cistercian nunnery at Swine in Yorkshire owned at one time what is now British Library MS Harley 2409: this includes a life of Catherine and also one of William Flete's texts. The Prioress of Swine, Matilda Wade (fl. I 482), gave this book to a nun at Nuneaton, a house of the order of Fontevrault, another double order of monks and nuns, founded in the twelfth century by Robert of Arbrissel. In 1485-6 another nun at Swine was bequeathed an English life of the saint by her aunt. And the late fifteenth-century book-list of the Augustinian Thurgarton Priory includes Latin texts of the Dialogo and of the saint's life.

\section{English women and continental Europe}

Such, then, are the women mystics and visionaries of whom Bishop Repingdon might have known. Some at least became known to Margery Kempe herself in due course. This was inevitable: Margery came from Lynn on the Norfolk coast, which in the Middle Ages was an important port with close ties to the Baltic, Scandinavia, and Flanders. She herself travelled extensively in Europe, on pilgrimages to the Holy Land via Rome and to Santiago da Compostela in Galicia, Spain; she also went to northern Germany, possibly via Sweden. She quite blatantly adopted Bridget of Sweden as a role-model and occasional rival: once when Margery witnessed at Mass the consecrated host flickering in the priest's hands, Our Lord assured her, 'My dowtyr, Bryde, say [saw] me neuyr in pis wyse' (BMK, p. 47/26-7). Hope Emily Allen, who rediscovered the unique manuscript of The Book of Margery Kempe in the I930s, was the first to suspect that the continental women visionaries exercised a strong influence on Margery's spirituality. The detailed work of more recent scholars has amply vindicated her hunch. Margery mentions Bridget's revelations ('Bride's book') in the same breath as Walter Hilton's writings, as the Stimulus amoris of James of Milan, and as Richard Rolle's Incendium amoris (BMK, p. 39/23-5): these were all texts read her by her confessor $\left(B M K, \mathrm{p} . \mathrm{I}_{43} / 27\right)$. Indeed on one occasion God himself vouched for their authenticity - 'it is trewe euery word pat is wretyn in Brides boke' (BMK, p. 47/33-4). As a pilgrim in Rome, Margery visited places that Bridget had visited ( $B M K$, p. 95/25-9) and interviewed people who had known her (BMK, p. 95/IO-22). Margery and her confessor also knew the revelations of 
St Elizabeth of Hungary ( $B M K$, p. I53/I3-I4 $)$, and the latter, at least, had read Jacques de Vitry's life of the Flemish beguine Mary of Oignies, as we have already seen.

More problematic, and perhaps more interesting, is whether Julian of Norwich knew anything of these continental women mystics. Julian was clearly trained, in the English tradition, to eschew visionary experience. She explains that, although her desire for 'mende of [Christ's] Passion' led her to request 'a bodily sight [vision] wherein I might have more knowledge of the bodily peynes [physical sufferings] of our saviour' (that is, perhaps, the kind of detailed vision of the Crucifixion experienced by Bridget), this was the extent of her mystical ambitions: 'Other sight ner sheweing [revelation] of God desired I never none till the soule was departid [separated] fro the body. ${ }^{20}$ Later, when apparently dying, she remembers this desire and again stresses, "But in this I desired never bodily sight nor sheweing of God."2 never refers to any visionaries by name but the desire she mentions in the course of her revelations for 'ful syte [comprehensive vision] of helle and purgatory' is intriguing. Many such revelations were granted to Bridget of Sweden, though it must be added that accounts of such Otherworld visions and voyages are common in the Middle Ages, such as the fifteenth-century revelation of Purgatory 'showed to a holy woman', ${ }^{22}$ (not to mention Dante's Divine Comedy). Julian is careful, however, to protest that she did not want any special insight - 'But it was not my mening to maken prive [be confidentally informed] of anything that longyth [appertains] to the feith"23 - nor was she prompted by lack of faith. When she goes further and wants information about the destiny of a particular person - whether 'a certeyn creature that I lovid' would persevere in virtuous living - she is refused an answer. ${ }^{24}$ This kind of curiosity about the fate of individual souls (Julian calls it 'syngular [specific] desire') is characteristic of Bridget and Mechthild, both of whom often sought, and were granted, such privileged information. ${ }^{25}$ Julian, in contrast, learns that 'it is mor worship [honour] to God to knowen al things in general than to lyken in onythyng in special'.

Julian, of course, is writing relatively early, in the last quarter of the fourteenth century. Clearly it was from the first quarter of the fifteenth century, particularly after the establishment of Syon Abbey, that continental women visionaries achieved such prominence as they would ever enjoy in England. It is equally clear that without the promotional activities of the Carthusians, as well as of the Bridgettine brethren, they would have made little if any impact on those people, whether lay men and women or female religious, who did not read Latin. As it is, their influence on the latter years of the Middle Ages in England must have been considerable if occasionally deplorable, as in the sad case of Elizabeth Barton, the Holy Maid of Kent. 
It is perhaps a measure of Britain's post-medieval insularity (encapsulated in the notorious but possibly apocryphal newspaper headline 'Fog in Channel - Continent Isolated') that we should find it slightly surprising, or intriguing, that writings of continental women mystics circulated in England. In the medieval mind England was, literally, marginalized. The thirteenthcentury Mappa Mundi preserved at Hereford Cathedral graphically represents the British Isles as two islands squeezed uncomfortably into the outer circumference of the known world. England was culturally subservient to France, from which it drew its dominant literary and artistic models, and spiritually dependent on Rome. Its rulers harboured extensive political and military ambitions towards France while they cultivated dynastic ties with ruling families all over Europe; its merchant classes were heavily reliant on trade with the greater European market.

But the trade in mystical texts was not all one-way. The Bridgettine motherhouse at Vadstena owned a manuscript containing two Latin texts by the mid-fourteenth-century Yorkshire mystic Richard Rolle (now Uppsala MS University C. I), while the Charterhouse at Enghien in Flanders also owned two Rolle manuscripts, now Brussels, Bibliothèque Royale MSS I 485 and 2103. The existence of Latin translations of the Middle English Mirror of Simple Souls, as of The Cloud of Unknowing, The Scale of Perfection, and the early thirteenth-century guide for anchoresses Ancrene Wisse, suggests that some clerics saw great possibilities for English mystical writings, if only they could be disentangled from the obscure and barbarous language in which they usually circulated!

But in the final analysis the continental women visionaries not only offered spiritual guidance: their very existence surely nourished extraordinary and, until then, unthinkable ambitions in their readers. One is tempted to say that these women must have been revelations in their own right. The very existence of the works of continental women visionaries in English translation must have served as a constant reminder that such women, who were not only mystics but also writers, did indeed exist - an existence otherwise only too easily forgotten.

\section{NOTES}

r. The Book of Margery Kempe, ed. Sanford Brown Meech and Hope Emily Allen, EETS OS 212 (London: Oxford University Press, r940), pp. 42/7-43/20. All subsequent references by page and line number are to this edition, cited as $B M K$.

2. Book for a Simple and Devout Woman, ed. F. N. M. Diekstra (Groningen: Egbert Forsten, I998), lines 7620-5.

3. Ibid., lines $7633-8$. 
4. Edited by C. Horstmann, 'Prosalegenden: Die Legenden des Ms. Douce II4', Anglia 8 (I 885 ): $134-84$.

5. The Book of Ghostly Grace, ed. Teresa Halligan (Toronto: Pontifical Institute for Mediaeval Studies, 1979). See also Women's Writing in Middle English, ed. Alexandra Barratt, Longman Annotated Texts (London: Longman, 1992), pp. 49-60.

6. M. Doiron, 'The mirrour of simple souls: A Middle English translation', Archivio Italiano per la Storia della Pietà 5 (I968), 247-355. See also Women's Writing in Middle English, ed. Barratt, pp. 6r-70.

7. Both versions have now been edited by Sarah McNamer, The Two Middle English Translations of the Revelations of St Elizabeth of Hungary, Middle English Texts 28 (Heidelberg: C. Winter, I996).

8. For a brief introduction and for edited extracts from some of the Middle English versions, see Women's Writing in Middle English, ed. Barratt, pp. 84-94.

9. One (that found in BL. MS Claudius B I) has been edited: see The Liber Coelestis of St Bridget of Sweden, vol. I: text, ed. by Roger Ellis, EETS OS 29I (Oxford University Press, I987).

10. Contemplations of the Dread and Love of God, ed. Margaret Connolly, EETS os 303 (Oxford University Press, I993).

II. See Women's Writing in Middle English, ed. Barratt, p. 85.

12. See The Revelations of Saint Birgitta, ed. W. P. Cumming, EETS os 178 (Oxford University Press, I 229), pp. xxxi-xxxvii.

13. See Christopher de Hamel, Syon Abbey: The Library of the Bridgettine Nuns and their Peregrinations after the Reformation (London: Roxburghe Club, I991), for a magisterial account of the surviving information.

14. 'The Rewyll of Seynt Sauioure' and Other Middle English Brigittine Legislative Texts, Vol. 2, ed. James Hogg, Salzburger Studien zür Anglistik und Amerikanistik 6 (Salzburg: Institut für Anglistik und Amerikanistik, 1978).

15. See Women's Writing in Middle English, ed. Barratt, pp. 30I-Io.

16. See The Bridgettine Breviary of Syon Abbey, ed. A. J. Collins, Henry Bradshaw Society 96 (Worcester: Stanbrook Abbey Press, 1969).

I7. Published as Liber Conventus S. Katherine Senensis prope Edinburgum, ed. J. Maidment (Edinburgh: Abbotsford Club, r 84I).

r8. The Orcherd of Syon, ed. Phyllis Hodgson and Gabriel M. Liegey, EETS os 258 (Oxford University Press, I966).

19. See Women's Writing in Middle English, ed. Barratt, pp. 95-107, for a brief note on Catherine and some extracts from the Middle English translation.

20. Julian of Norwich: A Revelation of Love, ed. Marion Glasscoe (Exeter University Press, I986, repr. r989), p. 2. Cf. Julian of Nortvich's Revelations of Divine Love: The Shorter Version, ed. Frances Beer, Middle English Texts 8 (Heidelberg: C. Winter, I978), p. 39/7, 2I-3 and pp. 39/26-40/I.

2I. Ibid., p. 4. Cf. Julian of Nonvich's Revelations, ed. Beer, p. 43/I-2.

22. In Women's Writing in Middle English, ed. Barratt, pp. $163-76$.

23. Ibid., p. 34. There is no parallel in the Shorter Version.

24. Ibid., p. 36. Cf. Julian of Norwich's Revelations, p. 64/16-I7.

25. See, for instance, the extract from Mechthild in Women's Writing in Middle English, ed. Barratt, pp. 58-60. 